\title{
IDENTIFIKASI SUMBERDAYA LAHAN PADA KETERSEDIAAN LOGAM BERAT (PB, CD DAN CR) TANAH SAWAH DI DAERAH PENGAIRAN SUNGAI CIKIJING KECAMATAN RANCAEKEK
}

\author{
Leony Agustine ${ }^{1}$, Rija Sudirja ${ }^{2}$, dan Rachmat Harryanto ${ }^{2}$ \\ ${ }^{1}$ Departemen Pascasarjana Ilmu Tanah, Fakultas Pertanian, Universitas Padjadjaran \\ ${ }^{2}$ Pengajar Departemen Ilmu Tanah, Fakultas Pertanian, Universitas Padjadjaran \\ Email: leony_ola@yahoo.com
}

\begin{abstract}
ABSTRAK
Penelitian ini bertujuan untuk: 1) mengevaluasi sebaran pencemaran ketersediaan logam berat $(\mathrm{Pb}, \mathrm{Cd}$ dan $\mathrm{Cr})$ dari pembuangan limbah pabrik tekstil terhadap tanah sawah di daerah pengairan Sungai Cikijing Kecamatan Rancaekek, 2) mengkaji kandungan ketersediaan logam berat ( $\mathrm{Pb}, \mathrm{Cd}$ dan $\mathrm{Cr}$ ) dan bahan organik yang terdapat pada tanah sawah di daerah pengairan Sungai Cikijing Kecamatan Rancaekek. Penelitian dilaksanakan pada lahan sawah tercemar logam berat dari limbah pabrik tekstil dari pengairan sungai Cikijing Kecamatan Rancaekek dan dilanjutkan dengan analisis tanah di Laboratorium Kesuburan Tanah dan Nutrisi Tanaman Fakultas Pertanian Universitas Padjadjaran. Penelitian dilakukan dengan penetapan titik sampel didasarkan kepada sistem purposive random sampling. Jumlah sampel adalah 50 yang terletak pada 4 desa. Variabel yang diamati dan diukur dalam penelitian ini meliputi variabel utama yaitu kandungan ketersediaan logam berat $(\mathrm{Pb}, \mathrm{Cd}$, dan $\mathrm{Cr})$ dan variabel pendukung meliputi $\mathrm{C}$-organik tanah. Hasil penelitian menunjukkan bahwa kandungan ketersediaan logam berat setiap lokasi sampel masih berada dibawah batas kritis untuk logam berat $\mathrm{Pb}$, $\mathrm{Cd}$ dan $\mathrm{Cr}$.

Kata kunci- C-Organik, Limbah pabrik, Logam berat
\end{abstract}

\section{PENDAHULUAN}

Logam berat merupakan unsur yang sulit untuk dirombak sehingga akan terakumulasi dan mengendap pada jaringan tubuh sehingga dapat menimbulkan keracunan bagi manusia, hewan, tanaman apabila keberadaannya melebihi ambang batas (Nurjaya dkk, 2006). Identifikasi ketersediaan logam berat pada tanah sawah perlu dilakukan dengan tepat, hal ini dapat dilakukan melalui survei tanah. Survei tanah merupakan pekerjaan pengumpulan data kimia, fisik dan biologi di lapangan maupun di laboratorium dengan tujuan pendugaan lahan umum maupun khusus. Survei merupakan sebagian dari proyek, sedangkan proyek adalah suatu rangkaian kegiatan yang saling berkaitan untuk mencapai sasaran tertentu dan membutuhkan banyak sarana. Oleh karena itu agar survei dapat mencapai sasaran dengan biaya dan waktu seoptimal mungkin, perlu dilakukan perencanaan survei (Abdullah, 1993).

Tujuan survei tanah adalah mengklasifikasikan, menganalisis dan memetakan tanah dengan mengelompokkan tanah-tanah yang sama dan hampir sama sifatnya ke dalam satuan peta tanah tertentu dengan mengamati profil tanah atas warna, struktur, tekstur, konsistensi, sifat-sifat kimia dan lain-lain (Hardjowigeno, 2010).

Daerah penelitian didasarkan pada daerah pengairan sungai yang mengalami pencemaran lahan karena adanya limbah pabrik tekstil yaitu sungai Cikijing. Sungai Cikijing terdapat di Kecamatan Rancaekek, sungai ini mengaliri lahan persawahan diempat desa yaitu Desa Linggar, Desa Jalenggong, Desa Bojongloa Dan Desa Sukamulya. Daerah ini merupakan daerah potensial yang mengalami pecemaran logam berat Timbal ( $\mathrm{Pb}$ ), Kadmium (Cd), Kromium (Cr) sehingga keberadaan logam berat tersebut tersedia dalam tanah dan membahayakan bagi tanaman.

Tujuan penelitian ini adalah mengevaluasi sebaran pencemaran ketersediaan logam berat $(\mathrm{Pb}$, $\mathrm{Cd}$ dan $\mathrm{Cr}$ ) dari pembuangan limbah pabrik tekstil terhadap areal persawahan padi di daerah pengairan Sungai Cikijing Kecamatan Rancaekek, mengkaji kandungan ketersediaan logam berat ( $\mathrm{Pb}, \mathrm{Cd}$ dan $\mathrm{Cr}$ ) dan C-organik yang terdapat pada tanah areal persawahan padi di daerah pengairan Sungai Cikijing Kecamatan Rancaekek. 


\section{METODOLOGI PENELITIAN}

\section{A. Lokasi dan Waktu}

Penelitian ini dilaksanakan pada lahan sawah yang tercemar logam berat dari limbah pabrik tekstil dari pengairan pengairan sungai Cikijing yaitu di Desa Jelekong, Desa Linggar, Desa Bojongloa, dan Desa Sukamulya Kecamatan Rancaekek (Gambar 1). Analisis sampel tanah dilakukan di Laboratorium Kesuburan Tanah dan Nutrisi Tanaman Fakultas Pertanian Universitas Padjadjaran. Penelitian ini dilaksanakan pada bulan Februari 2017 sampai dengan November 2017, meliputi tahap: persiapan, pengumpulan data, pengecekan lapangan, analisis dan penulisan laporan.

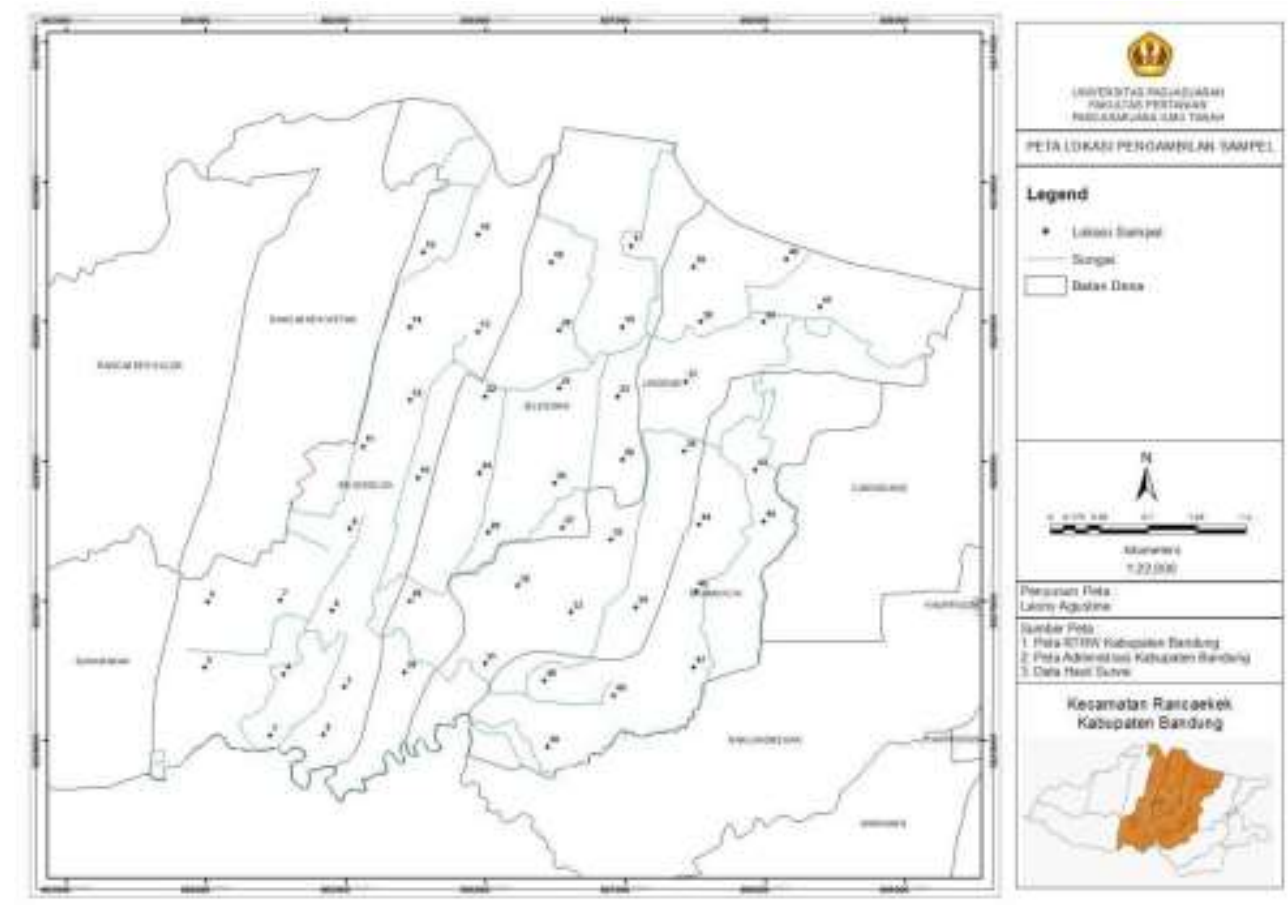

Gambar 1. Peta Lokasi Pengambilan Sampel

\section{B. Bahan dan Alat}

Bahan yang digunakan dalam penelitian ini untuk survei dan pemetaan meliputi: peta tematik RT RW Kecamatan Rancaekek yang meliputi peta kemiringan lereng, peta jenis tanah, peta penggunaan lahan, peta administrasi, kertas A3 (untuk mencetak peta), sampel tanah tercemar logam berat dan bahan untuk analisis sampel tanah di laboratorium. Alat yang digunakan dalam penelitian ini mencangkup alat-alat pembuatan peta, survei tanah dan analisis tanah di laboratorium. Alat untuk pembuatan peta yang digunakan yaitu PC (Komputer), Software GIS (Arc GIS 10.1) dan printer warna, alat untuk survei meliputi : altimeter, gps, pisau lapang, bor tanah, plastik sampel, alat tulis dan label serta alat-alat yang digunakan untuk analisis sampel tanah di laboratorium.

\section{Prosedur Penelitian}

Penelitian dilakukan dengan metode survei, pada tingkat ketelitian tinjau mendalam (semi detail) dengan skala peta 1: 25.000. Penentuan titik sampel dilakukan berdasarkan Peta Satuan Lahan Homogen (SLH), dibuat dengan cara menumpangsusunkan peta (overlay) dari peta administrasi, peta jenis tanah, peta kelerengan dan peta penggunaan lahan daerah penelitian. Sumber peta adalah peta tematik RT RW Kecamatan Rancaekek. Berdasarkan tata cara tersebut dipakai 1 kelas satuan lahan homogen yang terdapat pada Gambar 1. Berdasarkan tingkat ketelitian peta yang diuji, maka $25 \mathrm{Ha}$ lahan sawah diwakili oleh 1 sampel pengamatan. Berdasarkan kalkulasi peta SLH diperoleh 50 titik sampel pengamatan. Selanjutnya dilakukan survei ke lapangan dan pengambilan sampel tanah untuk dianalisis di Laboratorium. Pengambilan sampel tanah dilakukan dengan menggunakan bor tanah. Jenis sampel tanah berupa sampel tanah komposit, yang diambil pada kedalaman $0-30 \mathrm{~cm}$ dari lima titik yang berbeda. Sebaran titik sampel yang didapatkan dari peta SLH disajikan pada Tabel 1. 


\begin{tabular}{|c|c|c|c|c|}
\hline \multicolumn{5}{|c|}{ Tabel 1. Sebaran Titik Sampel } \\
\hline & & & & \\
\hline 1 & Iceptisol & $<8 \%$ & Bojongloa & 659'37.99"LS 10745'19.79"BT \\
\hline 2 & Iceptisol & $<8 \%$ & Bojongloa & $6^{\circ} 59^{\prime} 37.76 " \mathrm{LS} 107^{\circ} 45^{\prime} 31.93^{\prime \prime B T}$ \\
\hline 3 & Iceptisol & $<8 \%$ & Bojongloa & $6^{\circ} 59^{\prime} 26.54^{\prime \prime} \mathrm{LS} 107^{\circ} 45^{\prime} 36.45^{\prime \prime} \mathrm{BT}$ \\
\hline 4 & Iceptisol & $<8 \%$ & Bojongloa & $6^{\circ} 59^{\prime} 23.47^{\prime \prime L S} 107^{\circ} 45^{\prime 2} 21.88^{\prime \prime B T}$ \\
\hline 5 & Iceptisol & $<8 \%$ & Bojongloa & $6^{\circ} 59^{\prime} 22.14 " L S 107^{\circ} 45^{\prime} 3.90^{\prime \prime} \mathrm{BT}$ \\
\hline 6 & Iceptisol & $<8 \%$ & Bojongloa & $6^{\circ} 59^{\prime} 7.01$ "LS $107^{\circ} 45^{\prime} 4.63^{\prime \prime B T}$ \\
\hline 7 & Iceptisol & $<8 \%$ & Bojongloa & $6^{\circ} 59^{\prime} 6.43^{\prime \prime L S ~} 107^{\circ} 45^{\prime} 21.81 " \mathrm{BT}$ \\
\hline 8 & Iceptisol & $<8 \%$ & Bojongloa & $6^{\circ} 59^{\prime} 8.73$ "LS $107^{\circ} 45^{\prime} 33.81 " \mathrm{BT}$ \\
\hline 9 & Iceptisol & $<8 \%$ & Bojongloa & $6^{\circ} 58^{\prime} 49.16^{\prime \prime L S ~} 107^{\circ} 45^{\prime} 38.12^{\prime \prime B T}$ \\
\hline 10 & Iceptisol & $<8 \%$ & Bojongloa & $6^{\circ} 58^{\prime} 37.71^{\prime \prime L S} 107^{\circ} 45^{\prime} 53.81 " \mathrm{BT}$ \\
\hline 11 & Iceptisol & $<8 \%$ & Bojongloa & $6^{\circ} 58^{\prime} 30.54^{\prime \prime L S} 107^{\circ} 45^{\prime} 40.52^{\prime \prime B T}$ \\
\hline 12 & Iceptisol & $<8 \%$ & Bojongloa & $6^{\circ} 58^{\prime} 19.61^{\prime \prime L S} 107^{\circ} 45^{\prime} 51.20^{\prime \prime B T}$ \\
\hline 13 & Iceptisol & $<8 \%$ & Bojongloa & $6^{\circ} 58^{\prime} 3.90^{\prime \prime L S ~} 107^{\circ} 46^{\prime} 7.19^{\prime \prime B T}$ \\
\hline 14 & Iceptisol & $<8 \%$ & Bojongloa & $6^{\circ} 58^{\prime} 2.72$ "LS $107^{\circ} 45^{\prime} 51.42^{\prime \prime B T}$ \\
\hline 15 & Iceptisol & $<8 \%$ & Bojongloa & $6^{\circ} 57^{\prime} 45.37^{\prime \prime L S} 107^{\circ} 45^{\prime} 54.45^{\prime \prime B T}$ \\
\hline 16 & Iceptisol & $<8 \%$ & Bojongloa & $6^{\circ} 57^{\prime} 40.90^{\prime \prime} \mathrm{LS} 107^{\circ} 46^{\prime} 7.22^{\prime \prime B T}$ \\
\hline 17 & Iceptisol & $<8 \%$ & Jalegong & $6^{\circ} 57^{\prime} 43.53^{\prime \prime L S} 107^{\circ} 46^{\prime} 42.58^{\prime \prime B T}$ \\
\hline 18 & Iceptisol & $<8 \%$ & Jalegong & $6^{\circ} 57^{\prime} 47.41 " L S 107^{\circ} 46^{\prime 2} 23.99^{\prime \prime B T}$ \\
\hline 19 & Iceptisol & $<8 \%$ & Jalegong & $6^{\circ} 58^{\prime} 2.30^{\prime \prime L S} 107^{\circ} 46^{\prime} 41.10^{\prime \prime B T}$ \\
\hline 20 & Iceptisol & $<8 \%$ & Jalegong & $6^{\circ} 58^{\prime} 3.33^{\prime \prime L S} 107^{\circ} 46^{\prime} 26.29^{\prime \prime B T}$ \\
\hline 21 & Iceptisol & $<8 \%$ & Jalegong & $6^{\circ} 58^{\prime} 17.03^{\prime \prime L S} 107^{\circ} 46^{\prime} 26.50^{\prime \prime B T}$ \\
\hline 22 & Iceptisol & $<8 \%$ & Jalegong & $6^{\circ} 58^{\prime} 18.56^{\prime \prime L S} 107^{\circ} 46^{\prime} 8.71 " \mathrm{BT}$ \\
\hline 23 & Iceptisol & $<8 \%$ & Jalegong & $6^{\circ} 58^{\prime} 18.54^{\prime \prime L S} 107^{\circ} 46^{\prime} 39.76^{\prime \prime B T}$ \\
\hline 24 & Iceptisol & $<8 \%$ & Jalegong & $6^{\circ} 58^{\prime} 36.52^{\prime \prime L S} 107^{\circ} 46^{\prime} 7.87^{\prime \prime B T}$ \\
\hline 25 & Iceptisol & $<8 \%$ & Jalegong & $6^{\circ} 58^{\prime} 38.80^{\prime \prime L S} 107^{\circ} 46^{\prime} 25.23^{\prime \prime B T}$ \\
\hline 26 & Iceptisol & $<8 \%$ & Jalegong & $6^{\circ} 58^{\prime} 33.17^{\prime \prime L S} 107^{\circ} 46^{\prime} 41.28^{\prime \prime B T}$ \\
\hline 27 & Iceptisol & $<8 \%$ & Jalegong & $6^{\circ} 58^{\prime} 49.19^{\prime \prime L S} 107^{\circ} 46^{\prime 27.34 " B T}$ \\
\hline 28 & Iceptisol & $<8 \%$ & Jalegong & $6^{\circ} 58^{\prime} 50.40^{\prime \prime L S} 107^{\circ} 46^{\prime} 9.84^{\prime \prime B T}$ \\
\hline 29 & Iceptisol & $<8 \%$ & Jalegong & $6^{\circ} 59^{\prime} 6.57^{\prime \prime L S} 107^{\circ} 45^{\prime} 51.93 " \mathrm{BT}$ \\
\hline 30 & Iceptisol & $<8 \%$ & Jalegong & $6^{\circ} 59^{\prime} 23.14^{\prime \prime L S} 107^{\circ} 45^{\prime} 50.92^{\prime \prime B T}$ \\
\hline 31 & Iceptisol & $<8 \%$ & Linggar & 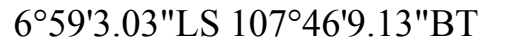 \\
\hline 32 & Iceptisol & $<8 \%$ & Linggar & $6^{\circ} 59^{\prime} 2.98^{\prime \prime L S} 107^{\circ} 46^{\prime} 17.01 " \mathrm{BT}$ \\
\hline 33 & Iceptisol & $<8 \%$ & Linggar & $6^{\circ} 59^{\prime} 8.89^{\prime \prime L S} 107^{\circ} 46^{\prime} 29.51^{\prime \prime B T}$ \\
\hline 34 & Iceptisol & $<8 \%$ & Linggar & $6^{\circ} 59^{\prime} 7.70^{\prime \prime} \mathrm{LS} 107^{\circ} 46^{\prime} 44.15^{\prime \prime} \mathrm{BT}$ \\
\hline 35 & Iceptisol & $<8 \%$ & Linggar & $6^{\circ} 58^{\prime} 51.96^{\prime \prime L S} 107^{\circ} 46^{\prime} 38.56^{\prime \prime B T}$ \\
\hline 36 & Iceptisol & $<8 \%$ & Linggar & $6^{\circ} 58^{\prime} 31.20^{\prime \prime L S} 107^{\circ} 46^{\prime} 55.30^{\prime \prime B T}$ \\
\hline 37 & Iceptisol & $<8 \%$ & Linggar & $6^{\circ} 58^{\prime} 14.80^{\prime \prime L S} 107^{\circ} 46^{\prime} 55.86^{\prime \prime B T}$ \\
\hline 38 & Iceptisol & $<8 \%$ & Linggar & $6^{\circ} 58^{\prime} 0.93^{\prime \prime L S} 107^{\circ} 46^{\prime} 58.77^{\prime \prime B T}$ \\
\hline 39 & Iceptisol & $<8 \%$ & Linggar & $6^{\circ} 57^{\prime} 48.32^{\prime \prime L S} 107^{\circ} 46^{\prime} 57.42^{\prime \prime B T}$ \\
\hline 40 & Iceptisol & $<8 \%$ & Linggar & $6^{\circ} 57^{\prime} 46.30^{\prime \prime L S} 107^{\circ} 47^{\prime} 19.03^{\prime \prime B T}$ \\
\hline 41 & Iceptisol & $<8 \%$ & Linggar & $6^{\circ} 57^{\prime} 57.12^{\prime \prime L S} 107^{\circ} 47^{\prime 2} 26.81^{\prime \prime B T}$ \\
\hline 42 & Iceptisol & $<8 \%$ & Linggar & $6^{\circ} 58^{\prime} 1.00^{\prime \prime L S} 107^{\circ} 47^{\prime} 14.07^{\prime \prime B T}$ \\
\hline 43 & Iceptisol & $<8 \%$ & Sukamulya & $6^{\circ} 58^{\prime} 35.36^{\prime \prime L S} 107^{\circ} 47^{\prime} 12.06^{\prime \prime B T}$ \\
\hline 44 & Iceptisol & $<8 \%$ & Sukamulya & $6^{\circ} 58^{\prime} 48.06^{\prime \prime L S} 107^{\circ} 46^{\prime} 59.05^{\prime \prime B T}$ \\
\hline 45 & Iceptisol & $<8 \%$ & Sukamulya & $6^{\circ} 58^{\prime} 47.19^{\prime \prime L S} 107^{\circ} 47^{\prime} 14.18^{\prime \prime B T}$ \\
\hline 46 & Iceptisol & $<8 \%$ & Sukamulya & $6^{\circ} 59^{\prime} 4.14 " \mathrm{LS} 107^{\circ} 46^{\prime} 58.20^{\prime \prime} \mathrm{BT}$ \\
\hline 47 & Iceptisol & $<8 \%$ & Sukamulya & $6^{\circ} 59^{\prime} 21.64^{\prime \prime L S} 107^{\circ} 46^{\prime} 57.98^{\prime \prime B T}$ \\
\hline 48 & Iceptisol & $<8 \%$ & Sukamulya & $6^{\circ} 59^{\prime} 24.83^{\prime \prime L S} 107^{\circ} 46^{\prime 23.45^{\prime \prime B T}}$ \\
\hline 49 & Iceptisol & $<8 \%$ & Sukamulya & $6^{\circ} 59^{\prime} 28.22^{\prime \prime L S} 107^{\circ} 46^{\prime} 39.23^{\prime \prime B T}$ \\
\hline 50 & Iceptisol & $<8 \%$ & Sukamulya & $6^{\circ} 59^{\prime} 40.12^{\prime \prime L S ~} 107^{\circ} 45^{\prime} 19.54 " \mathrm{BT}$ \\
\hline
\end{tabular}

Sumber: Hasil olah data dengan GIS (ArcGIS 10.1) 
Variabel yang diamati dalam penelitian adalah C-organik dan ketersediaan logam berat $(\mathrm{Pb}$, $\mathrm{Cd}$, dan $\mathrm{Cr}$ ). Data lapangan yang diperoleh berdasarkan hasil pengamatan di lapangan dan melalui wawancara dengan petani dan data analisis sampel tanah di laboratorium dikelompokkan dan disusun dalam tabel hasil kandungan ketersediaan logam berat. Nilai hasil analisis dikelompokkan berdasarkan kriteria penilaian hasil analisis tanah menurut Balai Penelitian Tanah (2005) dan Ministry of State for Population and Environment of Indonesia, and Dalhousie University, Canada (1992), selanjutnya data tersebut di kelompokkan ke dalam peta dengan menggunakan aplikasi GIS (Arc GIS 10.1).

\section{HASIL DAN PEMBAHASAN}

\section{A. Keadaan Umum Daerah Penelitian}

Jenis tanah yang terdapat di daerah pengairan Sungai Cikijing berdasarkan analisis spasial peta RT RW Kecamatan Rancaekek yaitu Inceptisols dan tidak terdapat jenis tanah lain di daerah penelitian ini. Kemiringan lereng yang didapatkan di daerah penelitian memiliki tingkat kemiringan lereng $<8 \%$ yang tergolong dalam kelas datar. Penggunaan lahan yang terdapat di daerah penelitian berupa sawah, pemukiman, perkebunan, tegalan, dan belukar.

\section{B. Kandungan C-Organik Tanah Sawah di Daerah Penelitian}

Hasil analisis kandungan C-organik tanah sawah pada daerah pengairan Sungai Cikijing tersaji pada Tabel 2, sedangkan sebaran C-organik pada daerah pengairan Sungai Cikijing terdapat pada Gambar 2. Klasifikasi kadar C-organik didasarkan atas kriteria penilaian C-organik menurut Balai Penelitian Tanah (2005).

Tabel 2. Hasil C-Organik

\begin{tabular}{cccccc}
\hline No Sampel & Hasil C $(\%)$ & Kriteria $^{\text {a) }}$ & No Sampel & Hasil C (\%) & Kriteria $^{\text {a) }}$ \\
\hline 1 & 1.59 & Rendah & 26 & 3.87 & Tinggi \\
2 & 2.54 & Sedang & 27 & 0.95 & Sangat Rendah \\
3 & 2.05 & Sedang & 28 & 3.27 & Tinggi \\
4 & 1.65 & Rendah & 29 & 3.23 & Tinggi \\
5 & 2.59 & Sedang & 30 & 2.98 & Sedang \\
6 & 2.23 & Sedang & 31 & 1.97 & Rendah \\
7 & 2.13 & Sedang & 32 & 1.74 & Rendah \\
8 & 2.17 & Sedang & 33 & 2.25 & Sedang \\
9 & 2.01 & Sedang & 34 & 1.24 & Rendah \\
10 & 3.58 & Tinggi & 35 & 2.98 & Sedang \\
11 & 2.21 & Sedang & 36 & 3.10 & Tinggi \\
12 & 2.38 & Sedang & 37 & 2.55 & Sedang \\
13 & 2.28 & Sedang & 38 & 1.94 & Rendah \\
14 & 1.78 & Rendah & 39 & 1.06 & Rendah \\
15 & 2.38 & Sedang & 40 & 2.13 & Sedang \\
16 & 2.25 & Sedang & 41 & 2.01 & Sedang \\
17 & 2.26 & Sedang & 42 & 1.88 & Rendah \\
18 & 1.51 & Rendah & 43 & 2.21 & Sedang \\
19 & 1.57 & Rendah & 44 & 1.97 & Rendah \\
20 & 2.17 & Sedang & 45 & 3.10 & Tinggi \\
21 & 1.05 & Rendah & 46 & 1.74 & Rendah \\
22 & 2.65 & Sedang & 47 & 3.21 & Tinggi \\
23 & 2.71 & Sedang & 48 & 1.59 & Rendah \\
24 & 3.68 & Tinggi & 49 & 2.42 & Sedang \\
25 & 2.81 & Sedang & 50 & 2.88 & Sedang \\
\hline
\end{tabular}

Keterangan: a) Balai Penelitian Tanah, 2005

Sumber: Hasil Analisis Laboratorium Ilmu Tanah Fakultas Pertanian UNPAD 
Hasil analisis C-organik di daerah pengairan Sungai Cikijing tergolong sangat rendah sampai tinggi (1.05-3,87). Hasil analisis C-organik menunjukkan lokasi sampel 27 sangat rendah yaitu 0,95, sedangkan hasil analisis tertinggi terdapat di lokasi sampel 26 yaitu 3,87. Beberapa proses yang dapat menyebabkan terjadinya kehilangan $\mathrm{C}$ dari dalam tanah dapat melalui (a) respirasi tanah, (b) respirasi tanaman, (c) terangkut panen, (d) dipergunakan oleh biota, dan (e) erosi. Peningkatan konsentrasi Corganik akan meningkatkan konsentrasi bahan organik yaitu asam humat dan asam fulfat dalam berintraksi dengan ion logam Cr. Senyawa humat juga berperan dalam membentuk ikatan kompleks dengan logam-logam. Adanya pembentukan kompleks mempengaruhi kereaktifan dan efek toksik dari logam (Matagi et al., 1998).

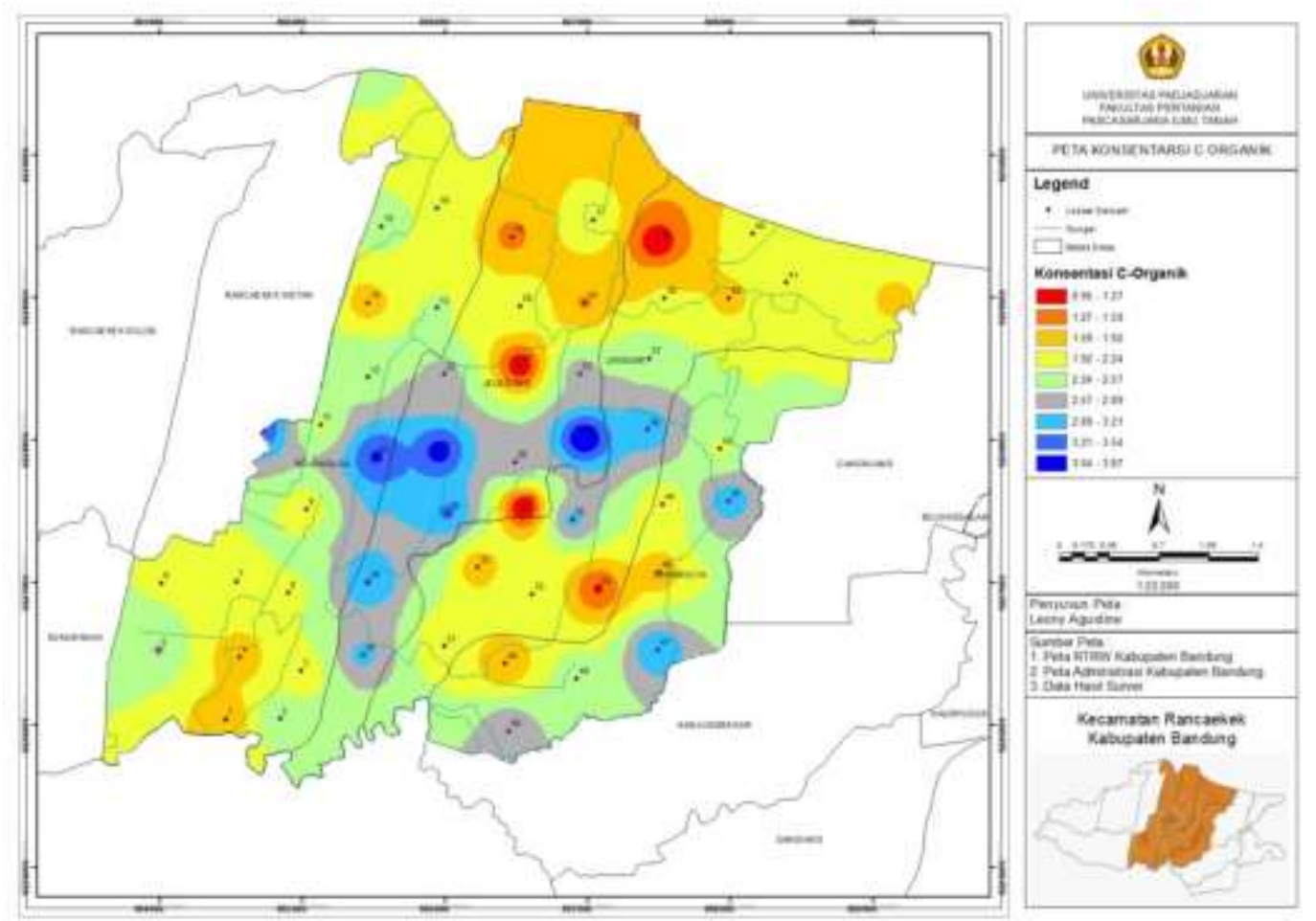

Gambar 2. Peta Konsentrasi C-Organik

\section{Kandungan Logam Berat di Daerah Penelitian \\ a. Logam Berat Pb Tersedia}

Hasil Analisis kandungan $\mathrm{Pb}$ tersedia pada tanah sawah di daerah pengairan Sungai Cikijing tersaji pada tabel 3. Klasifikasi batas kritis unsur logam berat $\mathrm{Pb}$ tersedia dalam tanah menurut Ministry of State for Population and Environment of Indonesia, and Dalhousie University, Canada (1992). Batas kritis untuk unsur $\mathrm{Pb}$ tersedia sebesar 100 ppm.

Hasil analisis dari Tabel 3 didapatkan bahwa daerah pengairan Sungai Cikijing telah mengalami pencemaran logam berat $\mathrm{Pb}$. Kandungan $\mathrm{Pb}$ tersedia bagi tanaman masih berada dibawah batas kritis tanah hal ini dikarenakan $\mathrm{Pb}$ Total yang terdapat didalam tanah jumlahnya masih dibawah baku mutu yang ditetapkan. Konsentrasi $\mathrm{Pb}$ tersedia dalam tanah tertinggi terdapat pada lahan sawah di desa Bojongloa pada sampel 13 yaitu 0,70 (Gambar 3). Tingginya konsentrasi $\mathrm{Pb}$ tersedia dalam tanah pada sampel 13 di Desa Bojongloa dikarenakan lokasi pengambilan sampel dekat dengan perumahan, hal ini dapat membuat lokasi sampel tersebut ikut tercemar limbah rumah tangga sehingga kandungan logam berat $\mathrm{Pb}$ tersedia pada lokasi ini tinggi.

Rendahnya $\mathrm{Pb}$ tersedia di daerah penelitian juga dikarenakan saat pengambilan sampel tanah dilakukan saat musim hujan. Menurut wawancara dengan petani setempat bahwa saat musim hujan air yang digunakan untuk pengairan lahan sawah di daerah penelitian menggunakan air tadah hujan tidak menggunakan air irigasi dari Sungai Cikijing yang tercemar limbah pabrik tekstil. 


\begin{tabular}{|c|c|c|c|c|c|}
\hline \multicolumn{6}{|c|}{ Tabel 3. Hasil Analisis Logam Berat $\mathrm{Pb}$ Tersedia } \\
\hline No Sampel & $\begin{array}{c}\text { Hasil } \\
\mathrm{Pb} \text { Tersedia } \\
\text { (ppm) }\end{array}$ & $\begin{array}{c}\text { Di Atas } \\
\text { Batas Kritis }\end{array}$ & No Sampel & $\begin{array}{c}\text { Hasil } \\
\mathrm{Pb} \text { Tersedia } \\
(\mathrm{ppm})\end{array}$ & $\begin{array}{c}\text { Di Atas } \\
\text { Batas } \\
\text { Kritis }^{\text {a) }}\end{array}$ \\
\hline 1 & 0.58 & Tidak & 26 & 0.22 & Tidak \\
\hline 2 & 0.59 & Tidak & 27 & 0.39 & Tidak \\
\hline 3 & 0.42 & Tidak & 28 & 0.21 & Tidak \\
\hline 4 & 0.48 & Tidak & 29 & 0.16 & Tidak \\
\hline 5 & 0.41 & Tidak & 30 & 0.01 & Tidak \\
\hline 6 & 0.45 & Tidak & 31 & 0.41 & Tidak \\
\hline 7 & 0.22 & Tidak & 32 & 0.29 & Tidak \\
\hline 8 & 0.42 & Tidak & 33 & 0.19 & Tidak \\
\hline 9 & 0.41 & Tidak & 34 & 0.15 & Tidak \\
\hline 10 & 0.27 & Tidak & 35 & 0.17 & Tidak \\
\hline 11 & 0.20 & Tidak & 36 & 0.59 & Tidak \\
\hline 12 & 0.29 & Tidak & 37 & 0.18 & Tidak \\
\hline 13 & 0.70 & Tidak & 38 & 0.12 & Tidak \\
\hline 14 & 0.27 & Tidak & 39 & 0.14 & Tidak \\
\hline 15 & 0.42 & Tidak & 40 & 0.17 & Tidak \\
\hline 16 & 0.26 & Tidak & 41 & 0.29 & Tidak \\
\hline 17 & 0.51 & Tidak & 42 & 0.12 & Tidak \\
\hline 18 & 0.18 & Tidak & 43 & 0.44 & Tidak \\
\hline 19 & 0.11 & Tidak & 44 & 0.27 & Tidak \\
\hline 20 & 0.49 & Tidak & 45 & 0.23 & Tidak \\
\hline 21 & 0.14 & Tidak & 46 & 0.14 & Tidak \\
\hline 22 & 0.07 & Tidak & 47 & 0.30 & Tidak \\
\hline 23 & 0.06 & Tidak & 48 & 0.01 & Tidak \\
\hline 24 & 0.29 & Tidak & 49 & 0.08 & Tidak \\
\hline 25 & 0.35 & Tidak & 50 & 0.22 & Tidak \\
\hline
\end{tabular}

Keterangan: ${ }^{\text {a) }}$ Ministry of State for Population and Environment of Indonesia, and Dalhousie University, Canada (1992)

Sumber: Hasil Analisis Laboratorium Ilmu Tanah Fakultas Pertanian UNPAD

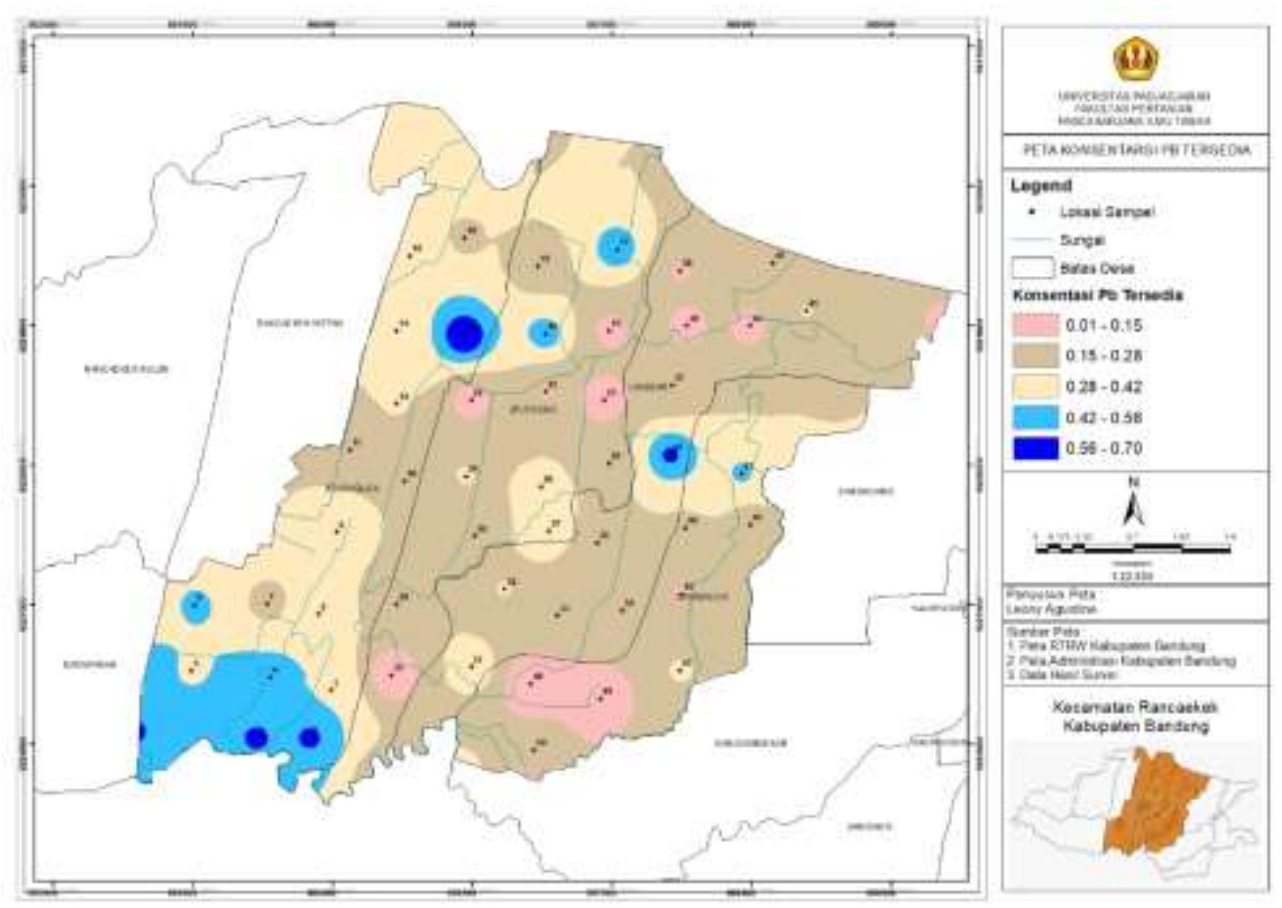

Gambar 3. Peta Konsentrasi Pb Tersedia 


\section{b. Logam Berat Cd Tersedia}

Tingkat $\mathrm{Cd}$ dalam lingkungan (tanah) tidak akan meningkat kecuali terjadi penambahan $\mathrm{Cd}$ akibat aktivitas manusia. Hasil Analisis kandungan $\mathrm{Cd}$ tersedia pada tanah sawah di daerah pengairan Sungai Cikijing tersaji pada Tabel 4. Klasifikasi batas kritis unsur logam berat Cd tersedia dalam tanah menurut Ministry of State for Population and Environment of Indonesia, and Dalhousie University, Canada (1992). Batas kritis untuk unsur Cd tersedia sebesar 0,50 ppm.

Tabel 4. Hasil Analisis Logam Berat Cd Tersedia

\begin{tabular}{cccccc}
\hline No Sampel & $\begin{array}{c}\text { Hasil Cd Tersedia } \\
(\text { ppm })\end{array}$ & $\begin{array}{c}\text { Di Atas } \\
\text { Batas Kritis })^{\text {) }}\end{array}$ & No Sampel & $\begin{array}{c}\text { Hasil Cd Tersedia } \\
(\text { ppm })\end{array}$ & $\begin{array}{c}\text { Di Atas } \\
\text { Batas Kritis }^{\text {a) }}\end{array}$ \\
\hline 1 & 0.15 & Tidak & 26 & 0.09 & Tidak \\
2 & 0.12 & Tidak & 27 & 0.09 & Tidak \\
3 & 0.12 & Tidak & 28 & 0.14 & Tidak \\
4 & 0.13 & Tidak & 29 & 0.14 & Tidak \\
5 & 0.10 & Tidak & 30 & 0.09 & Tidak \\
6 & 0.15 & Tidak & 31 & 0.08 & Tidak \\
7 & 0.11 & Tidak & 32 & 0.06 & Tidak \\
8 & 0.09 & Tidak & 33 & 0.09 & Tidak \\
9 & 0.12 & Tidak & 34 & 0.05 & Tidak \\
10 & 0.13 & Tidak & 35 & 0.11 & Tidak \\
11 & 0.14 & Tidak & 36 & 0.10 & Tidak \\
12 & 0.12 & Tidak & 37 & 0.16 & Tidak \\
13 & 0.14 & Tidak & 38 & 0.11 & Tidak \\
14 & 0.09 & Tidak & 39 & 0.04 & Tidak \\
15 & 0.14 & Tidak & 40 & 0.07 & Tidak \\
16 & 0.14 & Tidak & 41 & 0.10 & Tidak \\
17 & 0.17 & Tidak & 42 & 0.07 & Tidak \\
18 & 0.08 & Tidak & 43 & 0.09 & Tidak \\
19 & 0.09 & Tidak & 44 & 0.10 & Tidak \\
20 & 0.13 & Tidak & 45 & 0.14 & Tidak \\
21 & 0.04 & Tidak & 46 & 0.15 & Tidak \\
22 & 0.12 & Tidak & 47 & 0.11 & Tidak \\
23 & 0.09 & Tidak & 48 & 0.09 & Tidak \\
24 & 0.11 & Tidak & 49 & 0.08 & Tidak \\
25 & 0.11 & Tidak & 50 & 0.08 & Tidak \\
\hline
\end{tabular}

Keterangan: a) Ministry of State for Population and Environment of Indonesia, and Dalhousie University, Canada (1992)

Sumber: Hasil Analisis Laboratorium Ilmu Tanah Fakultas Pertanian UNPAD

Hasil analisis dari Tabel 4 didapatkan bahwa daerah penelitian telah mengalami pencemaran logam berat $\mathrm{Cd}$. Kandungan $\mathrm{Cd}$ tersedia bagi tanaman masih berada di bawah batas kritis tanah hal ini sesuai dengan keadaan yang menunjukkan bahwa kandungan logam berat $\mathrm{Cd}$ total yang terdapat dalam tanah rendah. Konsentrasi logam Cd tersedia dalam tanah yang paling tinggi terdapat pada lahan sawah di Desa Jelegong pada sampel 17 yaitu sebesar 0,17 (Gambar 4). Hal ini dikarenakan lokasi sampel 17 berada dekat dengan kawasan industri.

Meskipun hasil analisis laboratorium menunjukkan pencemaran logam berat $\mathrm{Cd}$ masih berada di bawah batas kritis tanah namun demikian menurut Alloway (1995), keberadaan Cd dalam tanah perlu diwaspadai mengingat sifatnya yang lebih mobil dalam tanah. Kadmium cenderung lebih mobil dalam tanah sehingga lebih tersedia bagi tanaman daripada logam lainnya seperti $\mathrm{Pb}$ dan $\mathrm{Cu}$. 


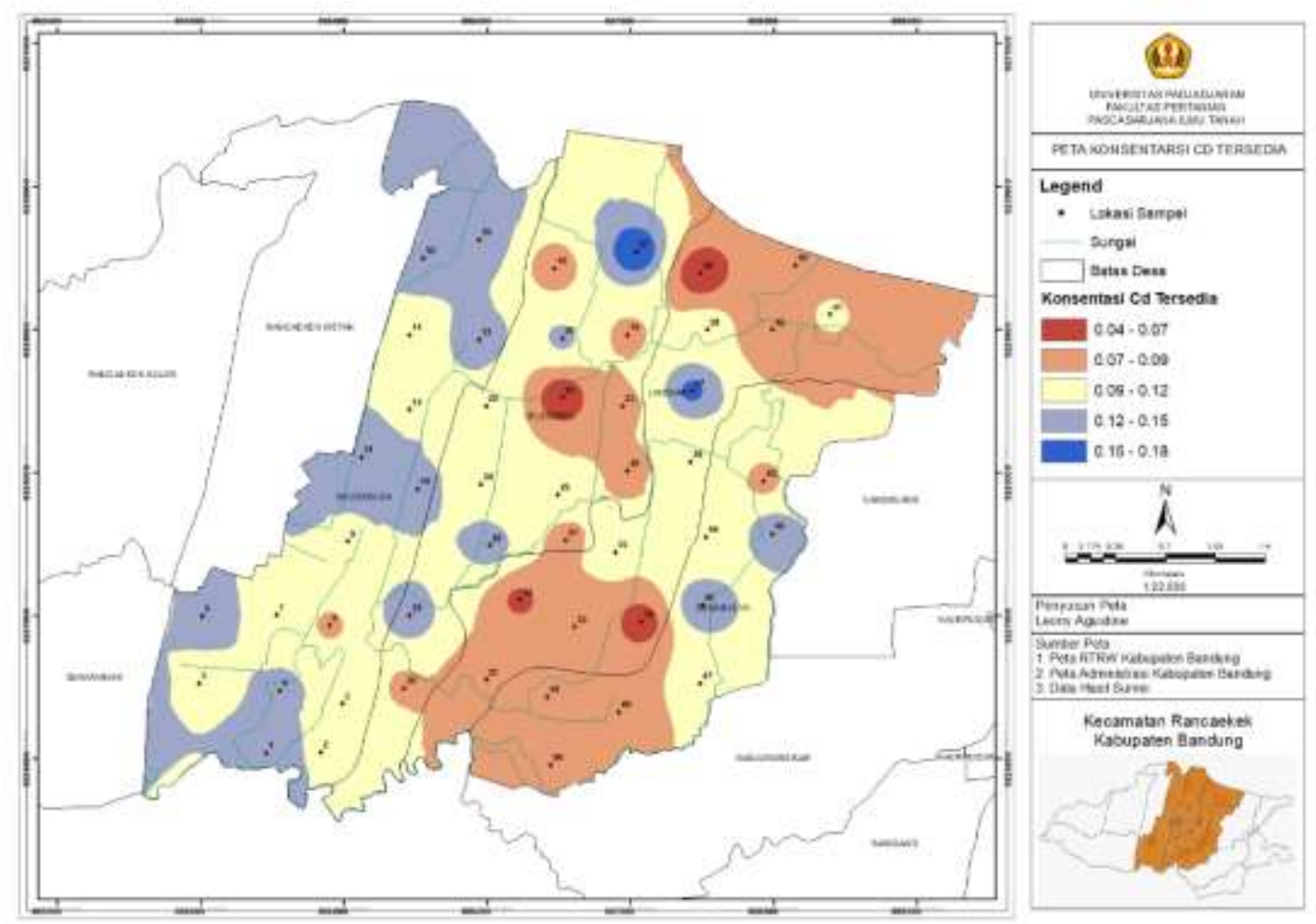

Gambar 4. Peta Konsentrasi Cd

\section{c. Logam Berat Cr}

Hasil Analisis kandungan Cr tersedia pada tanah sawah di daerah pengairan Sungai Cikijing tersaji pada tabel 5. Klasifikasi batas kritis unsur logam berat Cr tersedia dalam tanah menurut Ministry of State for Population and Environment of Indonesia, and Dalhousie University, Canada (1992). Batas kritis untuk unsur $\mathrm{Cr}$ tersedia sebesar 2,5ppm.

Hasil analisis dari Tabel 5 didapatkan bahwa daerah penelitian telah mengalami pencemaran logam berat $\mathrm{Cr}$. Kandungan $\mathrm{Cr}$ tersedia bagi tanaman hampir diseluruh lokasi sampel masih berada dibawah batas kritis tanah. Konsentrasi logam $\mathrm{Cr}$ tersedia dalam tanah yang paling tinggi dan beratas diatas batas kritis terdapat pada lahan sawah di desa Linggar pada lokasi sampel 37 yaitu sebesar 2,36 (Gambar 5), hal ini dikarenakan Desa Linggar merupakan lokasi pabrik tekstil berada dan lokasi sampel 37 merupakan hulu dari sungai Cikijing yang tercemar limbah pabrik.

Krom adalah salah satu logam berat yang dihasilkan dari proses produksi pada industri tekstil. Tingginya kandungan logam berat $\mathrm{Cr}$ akibat dari pembuangan limbah karena bahan kimia yang digunakan pada proses pewarnaan dan pencetakan pabrik tekstil. Senyawa krom di pabrik tekstil terutama digunakan dalam proses pencelupan yang menggunakan zat warna direk dan zat warna mordan. Salah satu zat warna direk adalah Congo Red (C.I. Direct red 28), sedangkan contoh zat warna mordan adalah Eriochrome Black T (C.I. Mordant Black 11) (Zille, 2005). 


\begin{tabular}{|c|c|c|c|c|c|}
\hline \multicolumn{6}{|c|}{ Tabel 5. Hasil Analisis Logam Berat Cr Tersedia } \\
\hline No Sampel & $\begin{array}{l}\text { Hasil Cr Tersedia } \\
\text { (ppm) }\end{array}$ & $\begin{array}{c}\text { Di Atas } \\
\text { Batas Kritis }^{\text {a) }}\end{array}$ & No Sampel & $\begin{array}{l}\text { Hasil Cr Tersedia } \\
\text { (ppm) }\end{array}$ & $\begin{array}{c}\text { Di Atas } \\
\text { Batas Kritis }^{\text {a) }}\end{array}$ \\
\hline 1 & 1.67 & Tidak & 26 & 0.55 & Tidak \\
\hline 2 & 1.66 & Tidak & 27 & 0.23 & Tidak \\
\hline 3 & 1.64 & Tidak & 28 & $<0.01$ & Tidak \\
\hline 4 & 1.80 & Tidak & 29 & $<0.01$ & Tidak \\
\hline 5 & 1.45 & Tidak & 30 & $<0.01$ & Tidak \\
\hline 6 & 1.46 & Tidak & 31 & 1.68 & Tidak \\
\hline 7 & 1.29 & Tidak & 32 & 0.88 & Tidak \\
\hline 8 & 1.44 & Tidak & 33 & 1.85 & Tidak \\
\hline 9 & 1.27 & Tidak & 34 & 0.77 & Tidak \\
\hline 10 & 1.13 & Tidak & 35 & 1.36 & Tidak \\
\hline 11 & 1.55 & Tidak & 36 & 1.97 & Tidak \\
\hline 12 & 1.00 & Tidak & 37 & 2.96 & $\mathrm{Ya}$ \\
\hline 13 & 1.17 & Tidak & 38 & 1.24 & Tidak \\
\hline 14 & 0.75 & Tidak & 39 & 1.60 & Tidak \\
\hline 15 & 0.80 & Tidak & 40 & 1.49 & Tidak \\
\hline 16 & 0.22 & Tidak & 41 & 1.48 & Tidak \\
\hline 17 & 0.02 & Tidak & 42 & 1.43 & Tidak \\
\hline 18 & $<0.01$ & Tidak & 43 & 1.64 & Tidak \\
\hline 19 & 0.42 & Tidak & 44 & 0.70 & Tidak \\
\hline 20 & $<0.01$ & Tidak & 45 & 1.34 & Tidak \\
\hline 21 & $<0.01$ & Tidak & 46 & 1.23 & Tidak \\
\hline 22 & $<0.01$ & Tidak & 47 & 1.24 & Tidak \\
\hline 23 & 0.01 & Tidak & 48 & 1.02 & Tidak \\
\hline 24 & 1.31 & Tidak & 49 & 0.62 & Tidak \\
\hline 25 & 0.55 & Tidak & 50 & 1.38 & Tidak \\
\hline
\end{tabular}

Keterangan: a) Ministry of State for Population and Environment of Indonesia, and Dalhousie University, Canada (1992)

Sumber: Hasil Analisis Laboratorium Ilmu Tanah Fakultas Pertanian UNPAD



Gambar 5. Peta Konsentrasi Cr 


\section{KESIMPULAN}

Terdapat sebaran pencemaran ketersediaan logam berat baik untuk unsur $\mathrm{Pb}, \mathrm{Cd}$, dan $\mathrm{Cr}$ dari pembuangan limbah pabrik tekstil terhadap tanah sawah pada daerah pengairan Sungai Cikijing di Kecamatan Rancaekek. Kandungan logam berat tersedia untuk $\mathrm{Pb}$ dan $\mathrm{Cd}$ masih di bawah batas kritis namun untuk $\mathrm{Cr}$ pada lokasi sampel 17 kandungan ketersediaan logam berat berada di atas batas kritis.

\section{SARAN}

Berdasarkan hasil pengamatan di daerah penelitian rekomendasi yang dapat dilakukan yaitu perlumya dilakukan penelitian lebih lanjut di lokasi yang sama pada musim yang berbeda sehingga dapat diketahui keberadaan logam berat pada setiap musim tanam dan dapat dibuat alternatif penanggulangannya dengan tepat.

\section{DAFTAR PUSTAKA}

Abdullah, T. S. 1993. Survei Tanah dan Evaluasi Lahan. Penebar Swadaya, Jakarta.

Alloway BJ. 1995. The origins of heavy metals in soils. Di dalam: Alloway BJ, editor. Heavy Metals in Soils. $2^{\text {nd }}$ Ed. Glasgow UK: Blackie Academic \& Professional. hlm 38-57.

Balai Penelitian Tanah. 2005. Petunjuk Teknis Analisis Kimia Tanah, Tanaman, Air dan Pupuk. Balai Penelitian Tanah, Badan Penelitian dan Pengembangan Pertanian, Bogor.

Hardjowigeno, S. 2010. Ilmu Tanah. Akademika Pressindo, Jakarta.

Matagi, S. V., Swai, D., and Mugabe, R., 1998. Heavy metal removal mechnisms in Wetlands. Afr. J. Trop. Hidrobiol. Fish. 8:23-35.

Ministry of State for Population and Environment Republic of Indonesia and Dalhousie University Canada. 1992. Environmental Management in Indonesia. Report on Soil Quality Standards for Indonesia (interim report).

Nurjaya, E. Zihan, dan M. Sri Saeni. 2006. Pengaruh Amelioran terhadap Kadar Pb Tanah, Serapannya serta Hasil Tanaman Bawang Merah pada Inceptisols. Jurnal Ilmu-ilmu Pertanian Indonesia. Vol 8, (2), Hal. 110-119.

Zille, A. 2005. Laccase Reaction for Textile Application I, Disertasi. Textile Department Universidade do Minho, Portugal. 